\title{
Analysis on Influencing Factors of Urban Smart Home-Based Elderly Care Satisfaction
}

\author{
Ran Zhang \\ Institute of Political Science and Law \\ University of Jinan \\ Jinan 250022, China
}

\author{
Zonghua $\mathrm{Li}^{*}$ \\ Institute of Political Science and Law \\ University of Jinan \\ Jinan 250022, China \\ *Corresponding Author
}

\begin{abstract}
Based on the survey data of a community in Shanghai, this paper analyzes the satisfaction of the elderly in China. The results show that health, economic and family status have a significant impact on the elderly's satisfaction of smart home-based care. Health status, economic status and family status have a significant impact on the elderly's satisfaction of smart home-based care. With the development of society and science and technology, the advantages and problems of smart pension in the promotion process will be more significant.
\end{abstract}

\section{Keywords-Smart pension; Aging; Satisfaction}

\section{QUESTION RAISED}

At present, China is entering a stage of rapid aging population development. According to the 2017 statistical bulletin on national economic and social development issued by the national bureau of statistics, by the end of 2017, China's elderly population aged 60 and above had reached 240.9 million, accounting for 17.3 percent of the country's total population. Thus it can be seen that smart pension as a new pension model has been taken seriously by the state. There are still some deficiencies in the existing studies on the definition of the concept of intelligent pension and the construction of the service system. In addition, most of the researches are in the aspects of engineering and management, and there is little research on sociology. Most of the researches on intelligent endowment discuss the construction of the elderly service system from a macro perspective, and few research and analyze the implementation of intelligent endowment. Along with the social progress and the development of science and technology, intelligent endowment advantages and problems in the process of popularization of also will be more obvious, through questionnaire survey and in-depth interview method further study of the pension situation wisdom, insight into the actual demand in the elderly, enrich the related research and development of intelligent home endowment has certain reference significance.

\section{LITERATURE REVIEW}

In November 2008, IBM first proposed the concept of "smart earth" at the council on foreign relations in New York, and proposed the connotation and vision of "smart city" in 2010.The foundation that young people enjoy the technology bring convenience when why old people can't, and plans to create wisdom endowment old apartment, use of modern science and technology products, assist the elderly endowment, at the same time for the elderly daily life in a state of remote monitoring, prevention and emergency and no one knows, provides the high quality for the elderly, intelligent life. So far, "wisdom endowment" has put forward a new idea and a new channel for all countries in the world. Then more and more scholars at home and abroad began to discuss the study of intelligent pension and put forward their own ideas.

Demiris (2001) went further in his definition of smart pension. He believed that smart pension mainly enables the elderly to achieve a better independent life by remote monitoring with technology and equipment [1].In domestic research, the definition of the concept of intelligent pension has been carefully combed. Intelligent pension has evolved from the "digital pension" proposed by hu liming in 2007 [2],Later, the academic circles, such as Liu Mancheng, Zuo Meiyun and Li Qiudi, have quoted "information-based pension" [3],Then, Zou Hua and Ma Fengling mentioned the concept of "technological endowment" for the first time after their conceptual evolution [4].On the other hand, make good use of the wisdom of the elderly, and finally create a healthy, convenient, pleasant, dignified and valuable old age life for the elderly [5].It is the integration of Internet information technology and elderly care services [6], and it meets the multilevel needs of elderly care by means of information technology [7].Liu Jianbing is more detailed concepts are given, that wisdom endowment is a creative process, not just a "concept" word, put forward the different times of the product would be for pension service of science and technology, create the diversity of pension services, enhance the level of pension services and meet the demand of endowment, science and technology innovation to boost traditional pension model change upgrades, and pratt \& whitney all old man [8].

\section{RESEARCH DESIGN}

\section{A. Data and Samples}

In this paper, a community in Shanghai was selected for investigation, and the elderly in this community were investigated by questionnaire. In terms of sampling, the empirical rule is that the smaller the population is, the larger the sampling ratio is in order to get an accurate sample, that is, 
a sample with a high probability of getting the same result as the population. The total number of elderly population in this community is 1,603 , which belongs to a small population. In order to achieve a high accuracy, the sampling ratio of $30 \%$ belongs to a high precision, which is about 307 samples. In this survey, 350 points of questionnaire were distributed and 336 copies were collected, among which 307 were valid, which met the standard of high accuracy.

\section{B. Dependent Variable}

This paper takes the question "how satisfied are you with the current smart home-based care" as the dependent variable, and the options are "very satisfied, relatively satisfied, average, relatively dissatisfied, and dissatisfied". In order to facilitate analysis, this paper recodes the words "very satisfied, satisfied and general" into "satisfied", and the words "very dissatisfied and dissatisfied" into "dissatisfied".

\section{Independent Variable}

Three independent variables were selected, namely, physiological health status, economic status and family status. Physical condition: "how is your physical health, whether you have a serious disease"; financial condition: "how much is your annual income?"; family status: "do your children support the smart home-based care model you currently accept?"

In terms of old-age security, the question is: "what kind of basic old-age insurance provided by the local government are you currently involved in?"

\section{Control Variable}

The control variables were sex, age, marital status and educational level.

\section{E. Research Hypothesis}

Hypothesis 1: The better the physical health, the higher the satisfaction of the elderly;

Hypothesis 2: The better the economic situation, the higher the satisfaction of the elderly;

Hypothesis 3: The more positive the children's attitude, the higher the satisfaction of the elderly.
TABLE I. BASIC INFORMATION OF THE SAMPLES

\begin{tabular}{|c|c|c|c|c|}
\hline $\begin{array}{l}\text { Variable } \\
\text { name }\end{array}$ & Variable value & $\begin{array}{l}\text { Frequenc } \\
\text { y (unit) }\end{array}$ & $\begin{array}{l}\text { Percentag } \\
\text { e }(\%)\end{array}$ & $\begin{array}{l}\text { Cumulat } \\
\text { ve } \\
\text { percenta } \\
\text { ge }(\%)\end{array}$ \\
\hline \multirow{2}{*}{$\begin{array}{l}\text { Satisfactio } \\
\text { n }\end{array}$} & $\mathrm{No}=0$ & 71 & 23.4 & 23.4 \\
\hline & Yes $=1$ & 232 & 76.6 & 100 \\
\hline \multirow{2}{*}{ Gender } & Male $=0$ & 124 & 40.9 & 40.9 \\
\hline & Female $=1$ & 179 & 59.1 & 100 \\
\hline \multirow[b]{2}{*}{$\begin{array}{l}\text { Marital } \\
\text { status }\end{array}$} & No spouse $=0$ & 80 & 26.4 & 26.4 \\
\hline & $\begin{array}{c}\text { Have a } \\
\text { spouse=1 }\end{array}$ & 223 & 73.6 & 100 \\
\hline \multirow{5}{*}{ Age } & $60-65=0$ & 45 & 14.9 & 14.9 \\
\hline & $66-70=1$ & 123 & 40.6 & 55.4 \\
\hline & $71-75=2$ & 83 & 27.4 & 82.8 \\
\hline & $76-80=3$ & 25 & 8.3 & 91.1 \\
\hline & $81-85=4$ & 27 & 8.3 & 100 \\
\hline \multirow{4}{*}{$\begin{array}{l}\text { Education } \\
\text { level }\end{array}$} & $\begin{array}{c}\text { Primary } \\
\text { schools and } \\
\text { below }=0\end{array}$ & 19 & 6.3 & 6.3 \\
\hline & $\begin{array}{c}\text { Junior high } \\
\text { school and } \\
\text { technical } \\
\text { secondary } \\
\text { school=1 }\end{array}$ & 107 & 35.3 & 41.6 \\
\hline & $\begin{array}{c}\text { Senior } \\
\text { secondary and } \\
\text { tertiary } \\
\text { education=2 }\end{array}$ & 148 & 48.8 & 90.4 \\
\hline & $\begin{array}{c}\text { University } \\
\text { degree or } \\
\text { above }=3\end{array}$ & 29 & 9.6 & 100 \\
\hline \multirow{2}{*}{$\begin{array}{l}\text { Physical } \\
\text { health }\end{array}$} & $\mathrm{No}=0$ & 211 & 69.6 & 69.6 \\
\hline & Yes $=1$ & 92 & 30.4 & 100 \\
\hline \multirow{4}{*}{$\begin{array}{l}\text { Financial } \\
\text { situation }\end{array}$} & $\begin{array}{c}50000 \text { the } \\
\text { following }=0\end{array}$ & 22 & 7.3 & 7.3 \\
\hline & $\begin{array}{c}50000- \\
100000 .=1\end{array}$ & 117 & 38.6 & 45.9 \\
\hline & $\begin{array}{c}110000- \\
200000=2\end{array}$ & 148 & 48.9 & 94.7 \\
\hline & $\begin{array}{l}\text { More than } \\
200000=3\end{array}$ & 16 & 5.3 & 100 \\
\hline \multirow{2}{*}{$\begin{array}{l}\text { Children's } \\
\text { attitude }\end{array}$} & $\mathrm{No}=0$ & 46 & 15.2 & 15.2 \\
\hline & Yes $=1$ & 257 & 84.8 & 100 \\
\hline
\end{tabular}

\section{LOGISTIC REGRESSION ANALYSIS OF ELDERLY PEOPLE'S IDENTITY IN CHINA}

Since the satisfaction of the elderly with smart home-based care is affected by many factors, it is necessary to establish a regression model with more influencing variables to further analyze the satisfaction degree of the elderly with smart homebased care. Since the dependent variable of this study was a binary nominal variable, the binary Logistic regression model was used for analysis.

This paper first establishes a basic model composed of demographic factors. On this basis, three factors including health status, economic status and family status were successively included to obtain model 1 , model 2 , model 3 and model 4. Finally, all the research variables were incorporated into the basic model to obtain a complete model 5. The regression results are shown in Table II.

The binary Logistic regression model can be expressed as:

$$
\operatorname{Logit}[\mathrm{P}(y=1)]=\mathrm{a}+\beta_{1} X_{1}+\beta_{2} X_{2}+\cdots+\beta_{\mathrm{k}} X_{\mathrm{k}}
$$




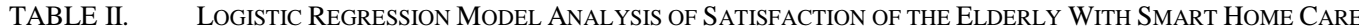

\begin{tabular}{|c|c|c|c|c|c|c|c|}
\hline \multirow{2}{*}{ Variable name } & \multirow{2}{*}{ Variable value } & \multicolumn{2}{|c|}{ Model 1} & \multicolumn{2}{|c|}{ Model 2} & \multicolumn{2}{|c|}{ Model 3} \\
\hline & & $\mathrm{B}$ & $\operatorname{Exp}(\mathrm{B})$ & $\mathrm{B}$ & $\operatorname{Exp}(\mathrm{B})$ & $\mathrm{B}$ & $\operatorname{Exp}(\mathrm{B})$ \\
\hline Gender(Male) & Female & 0.208 & 1.231 & 0.191 & 1.210 & 0.149 & $1.140 * *$ \\
\hline Marital status(No spouse) & Have a spouse & -0.55 & $0.573^{*}$ & -0.58 & 0.555 & -0.577 & 0.561 \\
\hline \multirow{4}{*}{$\operatorname{Age}(60-65)$} & $66-70$ & -0.34 & $0.454^{* *}$ & 0.345 & $1.412 * * *$ & 0.331 & 1.216 \\
\hline & $71-75$ & 0.204 & 1.226 & 1.027 & $1.207 * *$ & 0.316 & 1.217 \\
\hline & $76-80$ & -0.264 & 0.768 & 1.041 & $1.832 * *$ & 2.343 & 1.445 \\
\hline & $>81$ & 1.417 & 4.125 & 1.409 & 4.096 & 1.222 & 1.493 \\
\hline \multirow{3}{*}{$\begin{array}{c}\text { Education level(Primary schools } \\
\text { and belo) }\end{array}$} & $\begin{array}{l}\text { Junior high school and technical } \\
\text { secondary school }\end{array}$ & -0.03 & $0.966^{*}$ & 0.300 & $1.771 * * *$ & 0.443 & 1.451 \\
\hline & $\begin{array}{c}\text { Senior secondary and tertiary } \\
\text { education }\end{array}$ & -0.51 & $0.598^{* *}$ & 0.523 & $1.593 * * *$ & -0.333 & 0.223 \\
\hline & University degree or above & 0.514 & $1.598 * *$ & 0.523 & $1.227 * *$ & -0.17 & 0.332 \\
\hline Physical health(No) & Yes & -1.02 & $0.360 *$ & & & & \\
\hline \multirow{3}{*}{ Financial situation $(\leq \mathbf{5 0 0 0 0})$} & $50000-100000$ & & & 0.608 & $1.544 * * *$ & & \\
\hline & $110000-200000$ & & & 0.221 & $1.246^{* *}$ & & \\
\hline & $\geq 200000$ & & & -0.28 & $0.226^{* * * *}$ & & \\
\hline Children's attitude(No) & Yes & & & & & 0.334 & $2.143^{* *}$ \\
\hline
\end{tabular}

In model 1, regression analysis is mainly carried out on the basic demographic variables. As can be seen from the above table, gender has no significant influence on the satisfaction of the elderly with smart home-based care. In previous studies, it can be found that women are more likely to obtain satisfaction than men. However, in model 1, gender has no influence on the satisfaction of the elderly with smart home-based care. When the elderly quit the workplace, there is no longer too much competition and pressure in the elderly identity, and the difference between men and women is no longer prominent. Therefore, the gender difference of the elderly does not have a significant impact on smart home-based care.

In model 2 , factors of health status were incorporated into the model, and physiological health status was significant in the satisfaction of the elderly with smart home-based care. Hypothesis one is tested. In terms of physical health, the elderly with good physical health were 0.36 times more satisfied with smart home-based care than the elderly with poor physical health. This indicates that the elderly with poor physical health are more satisfied with smart home-based care. During the investigation, the community paid more attention to medical services. Most of the elderly had more time to pay attention to their own health problems after they were separated from the society. Therefore, the worse their physical health is, the more satisfied they are with smart home-based care.

In model 3, economic factors are added to the model. It can be seen from the table that the economic status has a significant influence on the satisfaction of the elderly with smart homebased care. Hypothesis 2 is verified. In terms of economic status, the occurrence ratio of the elderly with income of 60,000 to 100,000 yuan to the satisfaction of intelligent homebased care is 1.544 times that of the elderly with income of less than 50,000 yuan, and the occurrence ratio of the elderly with income of 110-200,000 yuan to the satisfaction of intelligent home-based care is 1.246 times that of the elderly with income of less than 50,000 yuan. This shows that when the income reaches more than 200,000 yuan, the elderly's satisfaction with the wisdom of pension will decrease. The income level of the elderly with personal annual income of more than 110,000 yuan is far higher than the pension level of the elderly in Shanghai, and their needs are not well met. The level of satisfaction in the elderly is higher, afford the corresponding costs at the same time, with the former, the description about the state of the economy difference conform to, and to verify.

In model 4, the family situation is included in the model, and the children's attitude indicates whether the children support the elderly to use the smart home-based care model. The results showed that the children's attitude had a significant influence on the satisfaction of the elderly with wisdom and care at home. Hypothesis 3 is verified. In terms of their children's attitude, the occurrence ratio of satisfaction with intelligent home-based care for the elderly with their children's supportive attitude is 2.143 times higher than that of the childless supportive elderly. In the smart home-based care, in addition to the service items provided by the community, the elderly can also buy smart care equipment. However, the elderly have limited access to this type of information, and the attitude of their children is more important. In the process of investigation, it was found that more elderly people used smart old-age care equipment provided by their children in their homes, which enabled them to clearly understand the real needs of the elderly and provide more accurate services corresponding to their needs, thus increasing their satisfaction with smart home-based old-age care services.

\section{CONCLUSION AND DISCUSSION}

According to the above analysis, with the continuous progress of China's social economy, the needs of the elderly are on the rise, and physiological needs are the primary needs 
of the elderly. Due to the attention paid to their own physiological health, health status has a significant impact on the satisfaction of the elderly with smart home-based care. The effect of economic status is not a general belief that the higher the economic income, the higher the satisfaction. The popularization of smart home-based care services in a certain range needs to be aimed more at the elderly with middle income, as well as the low-income and high-income groups. In terms of family status, children's attitude has a very significant influence on the satisfaction of the elderly with smart homebased care. As important family members, children's understanding of the real needs of the elderly and their proficiency in smart pension products and services make their support an important aspect affecting the satisfaction of the elderly with smart home-based care.

China's community smart home-based care is in the primary stage of development. A community smart home care service construction problems, is also the country's smart home community care service problems. Therefore, during the development period, the government should strive to promote the development of the elderly service industry, coordinate the material service and spiritual service, and integrate the community elderly service resources, so as to promote the rapid progress and development of intelligent elderly care in China.

\section{REFERENCES}

[1] Demiris, HenselB.K.Technologiesforan Aging Society: A systematic review of "smart home".

[2] Hu Liming, Wang Dongwei. New digital home-based community solutions for the aged [J]. Intelligent building, 2007 (11): 20-21.(In Chinese).

[3] Liu Mancheng, Zuo Meiyun, Li Qiudi. Study on the informatization demand of home-based elderly care based on community service [J]. Journal of information systems, 2012 (02): 87-99. (In Chinese).

[4] Zou Hua, Ma Fengling. Analysis of explanatory structure model of influencing factors of science and technology pension $[\mathrm{J}]$. China science and technology information, 2013 (03): 120-121. (In Chinese).

[5] Zuo Meiyun. Connotation, mode and opportunity of smart pension [J]. China public security, 2014 (10): 48-50. (In Chinese).

[6] Wu Leilei. Application of modern Internet of things technology in home-based elderly care services -- a case study of smart elderly care in shangcheng district, hangzhou $[\mathrm{J}]$. Contemporary social science perspectives, 2014 (03):17-19. (In Chinese).

[7] $\mathrm{Pu}$ Yaoqiong, Lu Mingway, Chen Dongfang. Analysis on the construction of smart pension model in nanan district, chongqing [J]. Journal of guangxi normal university (philosophy and social sciences edition), 2015,36 (04):80-82+92. (In Chinese).

[8] Liu Jianbing. Intelligent pension: from concept to innovation [J]. China information industry, 2015 (05): 90-93. (In Chinese). 